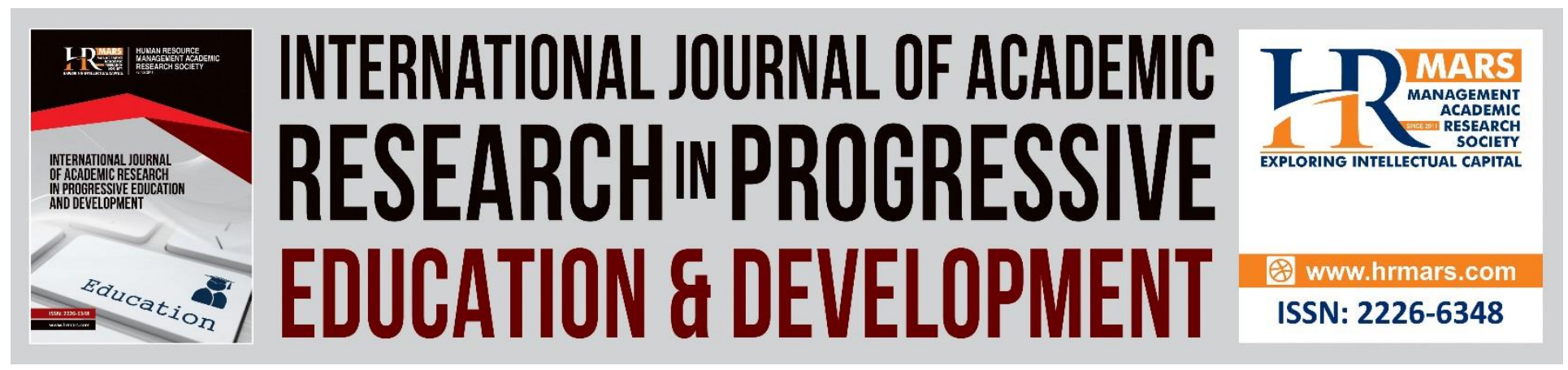

\title{
The Development and Evaluation of Learning Strategies Visualization (LSV) To Increase the Motivation and Knowledge of Student Learning Strategies Through Digital Storytelling Approach
}

\author{
M. Azwan Yusoff, Aidah A. Karim, H. Norman
}

To Link this Article: http://dx.doi.org/10.6007/IJARPED/v10-i1/8462

DOI:10.6007/IJARPED/v10-i1/8462

Received: 03 January 2021, Revised: 28 January 2021, Accepted: 11 February 2021

Published Online: 24 February 2021

In-Text Citation: (Yusoff et al., 2021)

To Cite this Article: Yusoff, M. A., Karim, A. A., \& Norman, H. (2021). The Development and Evaluation of Learning Strategies Visualization (LSV) To Increase the Motivation and Knowledge of Student Learning Strategies Through Digital Storytelling Approach. International Journal of Academic Research in Progressive Education and Development, 10(1), 36-50.

Copyright: (C) 2021 The Author(s)

Published by Human Resource Management Academic Research Society (www.hrmars.com)

This article is published under the Creative Commons Attribution (CC BY 4.0) license. Anyone may reproduce, distribute, translate and create derivative works of this article (for both commercial and non-commercial purposes), subject to full attribution to the original publication and authors. The full terms of this license may be seen at: http://creativecommons.org/licences/by/4.0/legalcode

Vol. 10(1) 2021, Pg. 36 - 50 


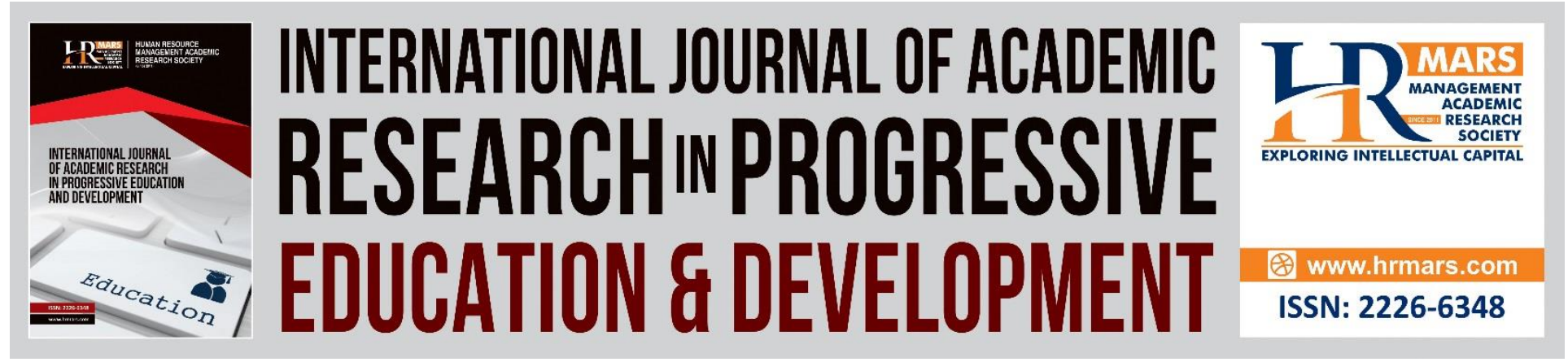

\title{
The Development and Evaluation of Learning Strategies Visualization (LSV) To Increase the Motivation and Knowledge of Student Learning Strategies Through Digital Storytelling Approach
}

\author{
M. Azwan Yusoff, Aidah A. Karim, H. Norman \\ Faculty of Education, Universiti Kebangsaan Malaysia, UKM Bangi, Selangor, Malaysia \\ Email: azwanukm@yahoo.com, eda@ukm.edu.my, helmi.norman@ukm.edu.my
}

\begin{abstract}
Nowadays, we need to be good at presenting to students so that students can understand the subject well while at the same time attracting their attention. Many university students are less knowledgeable about effective learning strategies that can help them in the day-to-day learning process. The purpose of this research is to design and develop Learning Strategies Visualization (LSV) online module, so students can learn high achieving student learning strategies from a digital storytelling approach. This research is based on ADDIE methodology, which consists of five phases, namely analysis, design, development, implementation and evaluation. Digital storytelling is an approach that presents learning materials in a storytelling mood, so that the student can understand well and influence the student emotionally. Digital storytelling also has 7 elements that can help storytellers build a good digital story. Besides, using digital storytelling approach, LSV also uses whiteboard animation as a concept and it will clarify a subject more clearly, help students constructing knowledge in the mind and visualize misconceptions. A survey of 72 students was conducted using questionnaires and descriptive statistical methods used to analyze the data. After implementation of LSV, the result showed that usability of LSV, knowledge of learning strategies and motivation of the student at the high level. At the end of this research, students who have participated are highly motivated and students will use high achieving learning strategies as student learning practices and lifelong learning.
\end{abstract}

Keywords: Digital Storytelling, Whiteboard Animation, Learning Strategies, ADDIE, Motivation, Knowledge

\section{Introduction}

Digital storytelling is used to create a short movie by integrating a computer-based software with digital objects such as text, images, music, video clips, and animation. These elements of digital media are combined and developed using specific computer software such as 
VideoScribe, Powtoon, PowerPoint and many more. Digital storytelling provides an opportunity for storytellers to convey stories more effectively through computer-based technology. Digital stories revolve around a theme selected, often have a certain point of view and usually only take a few minutes. Digital storytelling is not a new practice, considering it based on computer technology so it can be played by video file format such as MP4, FLV, AVI and WMV. Typically digital stories are uploaded to the internet and accessed through many social media platform such as YouTube, Facebook, Instagram and blog. Digital storytelling is being used in various ways globally, particularly in education, business, nonprofits organizations and community centers.

Joe Lambert, the co-founder of the Center for Digital Storytelling (CDS), now known as the StoryCenter in Berkeley, California, is one of the pioneers of this field. Since the beginning of the 1990s, the CDS has allowed young people and adults to build and share personal stories through the combination of insightful writing and digital content. CDS has played an important role in the development of digital storytelling and since its inception and to this day, a variety of workshops have been held to the public to help produce effective digital storytelling.

From the past research conducting by Yusoff et al. (2019), 10 learning strategies have been identified used by 4 high achieving students in UKM. At the university convocation ceremony, these 4 high achieving students had received the Royal Education Award and these students came from various faculties, such as Islamic Studies, Social Science \& Humanities, Economics and Management, and Medicine. Learning strategies are learning approaches used by students during the learning process, while effective learning strategies used by high achieving students that have an efficient cognitive system and they are capable of producing effective learning strategies (Ormrod, 2017). We ensure that these effective learning strategies can be learned and emulated by students using LSV through a digital storytelling approach. In Table 1, there are 10 learning strategies that have been used by 4 high achieving students to excel in academic. 
INTERNATIONAL JOURNAL OF ACADEMIC RESEARCH IN PROGRESSIVE EDUCATION AND DEVELOPMENT

Vol. 10, No. 1, 2021, E-ISSN: 2226-6348 @ 2021 HRMARS

\section{Table 1}

10 learning strategies that used by 4 high achieving students in UKM

\begin{tabular}{ll} 
Learning Strategies & Tactics \\
\hline 1. Visualization & $\begin{array}{l}\text { a. learning } \\
\text { b. idol } \\
\text { c. motivational words }\end{array}$ \\
\hline \multirow{3}{*}{ 2. Goals } & $\begin{array}{l}\text { a. the purpose of the study } \\
\text { b. the goal of socialization } \\
\text { c. career goal }\end{array}$ \\
\hline & a. conscious \\
3. Attitude & b. opportunistic \\
& c. confident \\
d. hard work \\
e. fast \\
f. spiritual
\end{tabular}

\begin{tabular}{ll}
\hline & a. identify your emotions \\
& b. control your emotions \\
4. Emotional Intelligence & c. recognize the emotions of others \\
& d. build relationship \\
d. motivate oneself
\end{tabular}
a. spesific website
b. internet video
c. internet search
d. social networks

5. Information Technology

6. Time Management

a. planning activities

b. planning priorities

\begin{tabular}{ll}
\hline 7. Learning Practices & $\begin{array}{l}\text { a. learning goals } \\
\text { b. learning styles } \\
\text { c. active learning } \\
\text { d. learning in class } \\
\text { e. learning environment }\end{array}$ \\
\hline 8. Note & $\begin{array}{l}\text { a. practice of writing notes } \\
\text { b. note style } \\
\text { c. visual note }\end{array}$ \\
\hline 9. Memorize & $\begin{array}{l}\text { a. acronym } \\
\text { b. loci } \\
\text { c. mnemonic }\end{array}$ \\
\hline a. Examination & $\begin{array}{l}\text { a. before the exam } \\
\text { b. during the exam } \\
\text { c. after the exam }\end{array}$ \\
\hline
\end{tabular}

This research was carried out from the continuation of the Yusoff et al. (2019) study on 
how learning strategies can be taught to students so that students can better understand them. We setting up our online module called LSV, which helps students to learn easily online in constructivist learning environment. Learning strategies visualization (LSV) is an online learning module that teaches high achieving learning strategies used by undergraduate students using digital storytelling approach. Visualization is the process of making pictures or movies in our minds (Wong, 2009). As a result, we use this term to ensure that students are always conscious of these learning strategies by encouraging their learning habits. Digital storytelling is an innovative pedagogical approaches that can engage students in meaningful learning with a constructivist learning environment (Smeda et al., 2014). Digital storytelling also can help an understanding of a subject presented and influence the audience emotionally. In terms of the capacity to hold the audience's attention, the necessity of digital story with emotional content will also be framed (Poletti, 2011). The research is guided by the following objectives:

i) Use effective learning strategies for LSV development.

ii) Design and develop the LSV for students.

iii) Identifying the level of usability of the LSV among students.

iv) Identifying the level of knowledge of learning strategies among students when using the LSV.

v) Identifying the level of motivation to learn among students when using the LSV.

The research questions in this research are as follows:

i) What are the effective learning strategies for LSV development?

ii) How the LSV designed and developed?

iii) What is the level of usability of the LSV among students?

iv) What is the level of knowledge of learning strategies among students when using LSV?

v) What is the level of motivation to learn among students when using the LSV?

\section{Methodology}

ADDIE is a product development with five step process of instructional design and an acronym for analyze, design, develop, implement, and evaluate. The ADDIE model is for intentional learning environments and fundamental process for creating effective learning (Branch, 2009). Robin \& McNeil (2012) suggest ADDIE for instructional design guidance and as starting points that educators should consider when starting to implement digital storytelling into their classrooms. In Table 2, all the description relating of the ADDIE model are explained. 
DEVELOPMENT

Vol. 10, No. 1, 2021, E-ISSN: 2226-6348 @ 2021 HRMARS

\section{Table 2}

The ADDIE model and a brief summary of each acronym are explained

\begin{tabular}{ll}
\hline Analysis & $\begin{array}{l}\text { Identify an educational objective and analyses the aspects of } \\
\text { the digital story related to the subject. }\end{array}$ \\
\hline Design & $\begin{array}{l}\text { Storyboard for story design, organizing appropriate media } \\
\text { such as images, audio and video. }\end{array}$ \\
\hline Development & Use multimedia software to build the digital storytelling. \\
\hline Implementation & Implementation of teaching. \\
\hline Evaluation & Conduct an assessment of the module.
\end{tabular}

\section{Analysis}

In this analysis phase, we identify an educational objective and analyze aspects of the digital story related to the issue. What exactly the student needs and makes learning more interesting. We use the interview method and ask what are the problems with the learning strategies of undergraduate students. When we analyze the needs and interview some of the students, there was a student who did not know about learning strategies and the students prefer online modules. We used the finding of Yusoff et al. (2019) to design and develop a digital storybased learning strategy module. This finding is learning strategies that the high achieving student use and should be required for this research.

\section{a. Design}

According to Lambert (2013), there are several production process approaches to produce digital storytelling such as : (1). Animation, (2). Voice photography, (3). Community pedagogy, (4). Audio storytelling, (5). Ethnographic history, (6). Transmedia. However, this research focuses on the animation category as a production process approach, where the animation is a type of whiteboard animation that uses the VideoScribe software. VideoScribe has been developed by Sparkol and is a specialized animation software for whiteboard animation production. Whiteboard animation is animation process which storyteller physically draws an illustrated story using a marker pen and whiteboard. Whiteboard animation is a new method of conveying information in learning where the animation used can explain more clearly about a topic or concept and help students constructing knowledge in the mind and visualize assumptions (Chiriacescu et al., 2020). The design of the LSV based on whiteboard animation concept can help in the learning process and convey emotions to students (Bradford \& Bharadwaj, 2015; Türkay, 2016).

Even though there are many ways for developing digital storytelling, Lambert has introduced 7 elements for digital storytelling where these elements are used as a guide in the digital storytelling development process (Lambert, 2007). Consideration of the use of these 7 elements of digital storytelling is important because these 7 elements are a proven method that produces high-quality digital storytelling. According to Gladstone \& Stasiulis (2019), the main purpose of the seven elements is to ensure that storytellers are able to create a good story because the narrative satisfies, surprises and engages the viewer. The following describes every 
Vol. 10, No. 1, 2021, E-ISSN: $2226-6348$ @ 2021 HRMARS

aspect of a successful digital story using 7 of the elements in Table 3, while Figure 1 illustrates the dramatic question and the economic elements used in LSV.

\section{Table 3}

The 7 elements of digital storytelling

\begin{tabular}{|c|c|}
\hline $\begin{array}{c}\text { Elements of } \\
\text { digital storytelling }\end{array}$ & Descriptions \\
\hline 1.Point of view & $\begin{array}{l}\text { A story about, specific or niche topic is better. The } \\
\text { storyteller will convey the focused subject to the } \\
\text { audience directly. The digital stories should be based on } \\
\text { the viewpoint of the storyteller and present the } \\
\text { significant point of the story. }\end{array}$ \\
\hline 2. Dramatic question & $\begin{array}{l}\text { Set the best narrative make audience surprise. A story } \\
\text { that draws the interest of the audience presents a } \\
\text { crucial question that is answered by the end of the story. } \\
\text { A successful digital story has a significant topic, which } \\
\text { increases the audience's curiosity and maintains the } \\
\text { audience's attention. }\end{array}$ \\
\hline 3. Emotional content & $\begin{array}{l}\text { A story that touched the hearts of the audience. } \\
\text { Emotional impact as one of the aspects of a successful } \\
\text { digital storytelling that will evokes emotions from the } \\
\text { audience. The audience could crying or express the } \\
\text { excitement that can make connection between the } \\
\text { audience and the story. }\end{array}$ \\
\hline 4. Voice & $\begin{array}{l}\text { Make a nice and clear voice. The voice of a storyteller } \\
\text { with a good narration in order to help the audience } \\
\text { better understand the content and make an impact of } \\
\text { the story. }\end{array}$ \\
\hline 5.Sound Track & $\begin{array}{l}\text { A background music that can influence the story. Adding } \\
\text { music or other forms of sound supports and strengthens } \\
\text { the plot and the depth of the narrative. }\end{array}$ \\
\hline 6. Economy & $\begin{array}{l}\text { Make it easy in simple words and pictures. Be accurate, } \\
\text { concise, and clear to provide the substance of the story. } \\
\text { Use only significant material and not burden the } \\
\text { audience with irrelevant information. }\end{array}$ \\
\hline 7.Pacing & $\begin{array}{l}\text { Give audience time to get into the story. The flow of the } \\
\text { story and relates with how slower or faster the plot goes } \\
\text { forward and it should be compatible with the intent of } \\
\text { the story. }\end{array}$ \\
\hline
\end{tabular}


INTERNATIONAL JOURNAL OF ACADEMIC RESEARCH IN PROGRESSIVE EDUCATION AND DEVELOPMENT

Vol. 10, No. 1, 2021, E-ISSN: 2226-6348 @ 2021 HRMARS

\section{Figure 1}

Dramatic question and economy elements are used in LSV

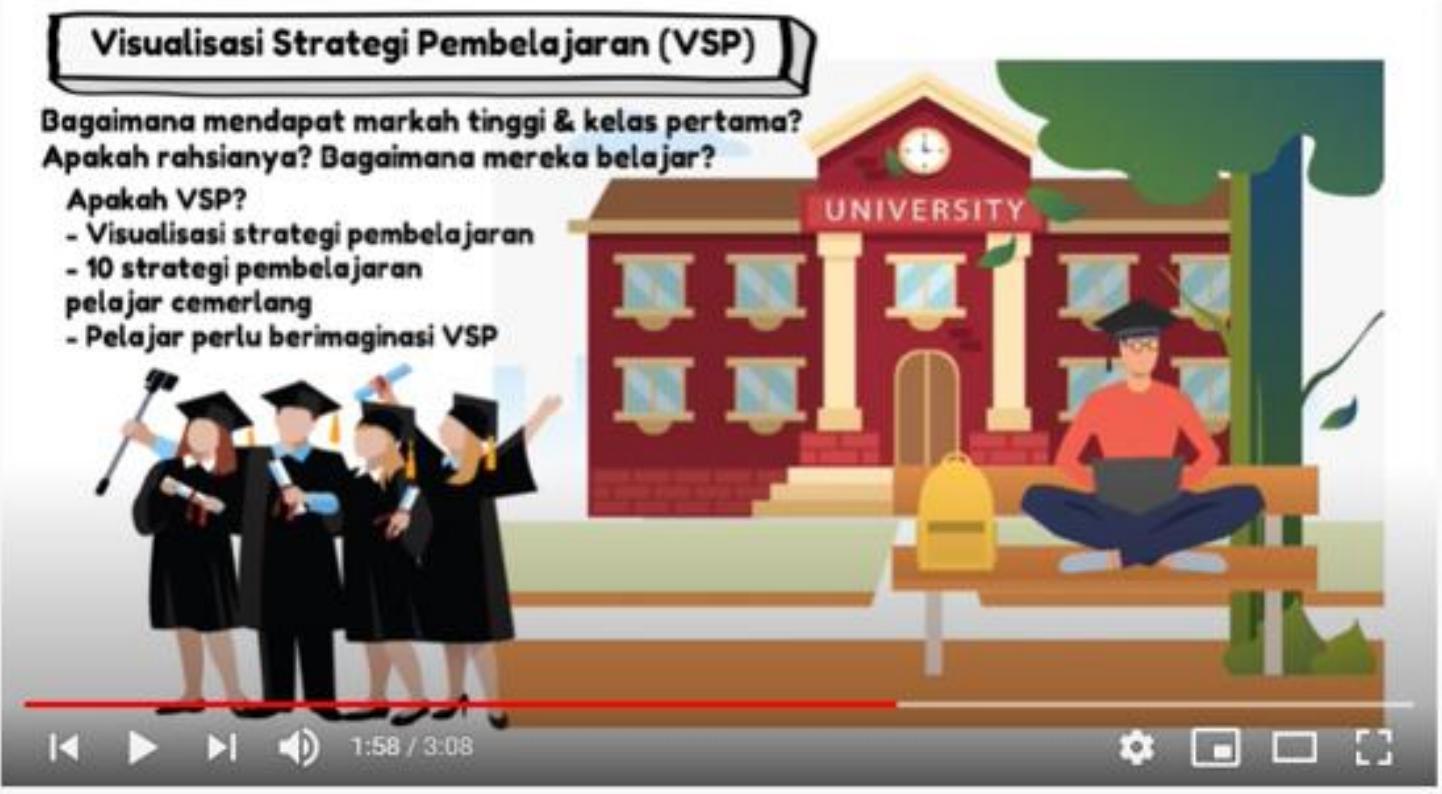

The storyboard serves as blueprint and a text or graphical outline of all the elements in the digital story (Robin \& McNeil, 2019). In this research, the software of Microsoft OneNote 2016 was used to create storyboard. This software makes it easy to produce storyboards because (1). There are elements of note storage in various categories, (2). Has the ability to create various text elements, (3). Can draw a flow chart and table, (4). Has elements can include pictures, videos and audio, (5). Storage in the cloud. Storyboard is an important aspect to visualize the entire journey of the project in the developer's view, so if there is an element left behind, we can add it to the storyboard. In Figure 2, an example of a storyboard used to illustrate the LSV using Microsoft OneNote 2016. 
Vol. 10, No. 1, 2021, E-ISSN: 2226-6348 @ 2021 HRMARS

\section{Figure 2}

Storyboard for LSV using Microsoft OneNote 2016

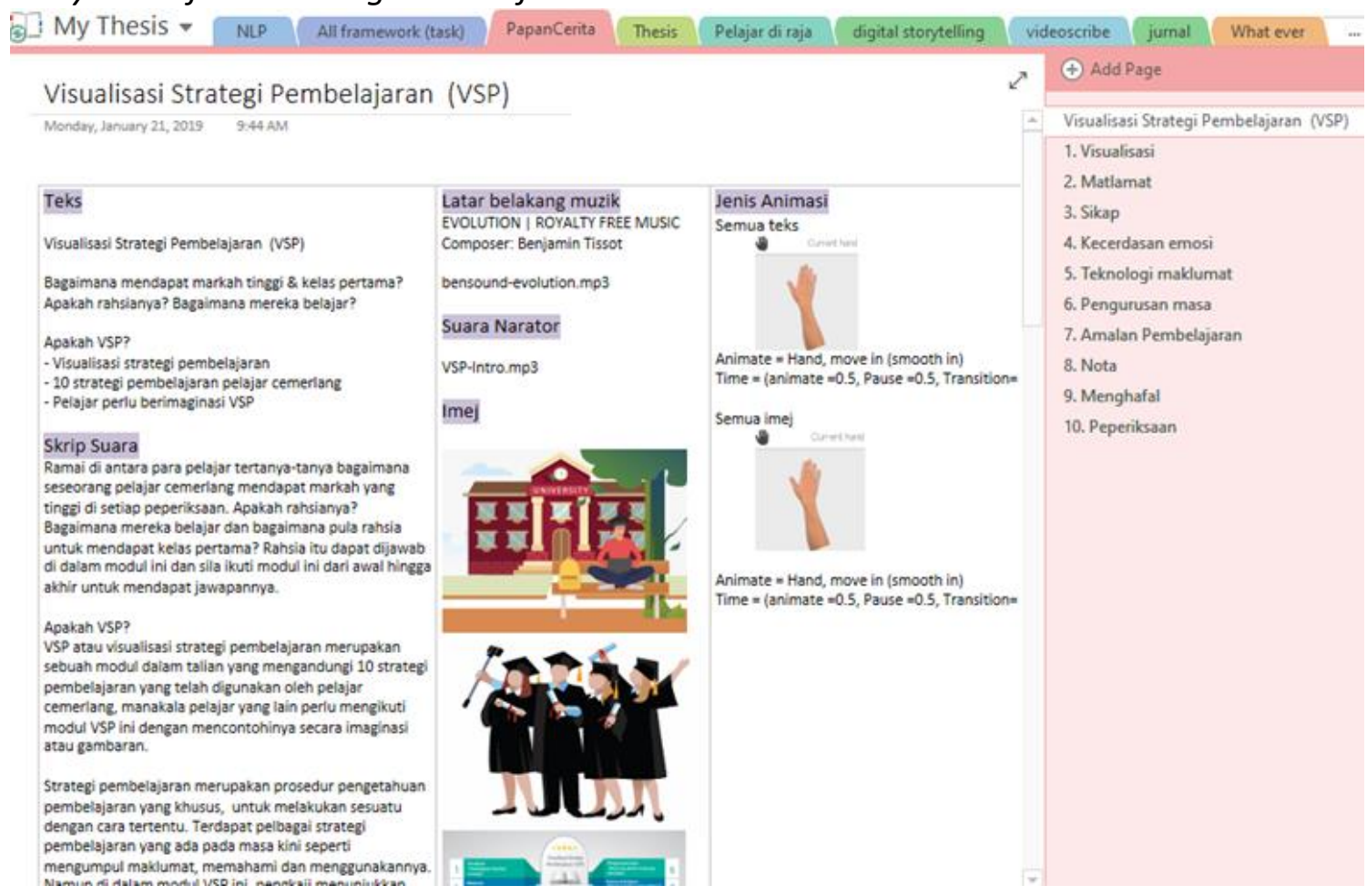

\section{b.Development}

In whiteboard animation development, VideoScribe is the primary software because it suits the digital storytelling concept and is convenient to use. There are many other applications on the market, such as Explaindio, Powtoon, Doodly, VideoMakerFX, and many more. Whiteboard animation and digital storytelling can draw attention and focus for young people (Bradford \& Bharadwaj, 2015). The LSV is developed on YouTube as an online video sharing platform for a digital storytelling and whiteboard animation approach. We preferred YouTube as an learning video platform because YouTube is simple, easy to operate and students use YouTube more than any other video platform. Besides, the YouTube is a user-friendly interface design and is favorite channel of the student from our interview. In the 21st century, online learning activities have become a necessity and with the advancement of video technology such as YouTube, students can browse it anywhere through the internet. Apart from YouTube, other online video sharing platform include DailyMotion, Vimeo, Facebook Video and Instagram Video.

Audacity software is used to record and edit narrative audio, so it's easy to use. Voice recordings of the narrator are first recorded using Audacity software and then edited to remove unwanted audio. Audio quality will be enhanced by using the audio track function so that the voice of the narrator can be heard louder and clearer. The audio format is exported to the $\mathrm{mp} 3$ format compared to the wav format, as the $\mathrm{mp} 3$ format is smaller after compression. Background music or soundtrack is also used and downloaded free of charge from popular websites like bensound.com. 


\section{c. Implementation}

The implementation phase is the execution phase of the learning environment in the actual teaching context, where students are involved in the acquisition of new knowledge and skills (Branch, 2009). Before learning begins, points to remember are: (i). Preparation for students (ii). Facility of lab (iii). Hardware and software for learning (iv). Stable internet access (v). Appropriate timetable or schedule. This phase concentrated on 72 randomly selected students from the faculty of education and engineering, conducted at the recommended time in a computer lab. Learning takes about 1 hour through online and all event layouts are shared with students.

\section{d. Evaluation}

This evaluation phase will be focus based on the usability, knowledge, motivation of the LSV after the implementation phase. To make the LSV more efficient, this evaluation process needs to be done to fix existing weaknesses. The instrument used in the evaluation phase is a questionnaire, the questionnaire in this research consisted of a Likert scale where Rensis Likert, as founder explained ordinal data have provided a range of responses to each question or statement provided to respondents (Cohen et al., 2018). The evaluation questionnaire consists of three parts, namely the usability section of 27 items, knowledge of 11 items and motivation of 31 items. The results are in quantitative form and the descriptive statistical analysis method is used to analyses quantitative data using Excel software, which requires the calculation of mean values. A descriptive description is then provided to explain the results obtained.

\section{Result}

A survey of 72 students was conducted to evaluate the usability of LSV, the motivation and knowledge of students in learning strategies using the questionnaire. A total of 14 items of the usability questionnaire, 11 items of the knowledge questionnaire and 31 items of the motivation questionnaire were made available online using google form to the students after the implementation of the LSV. The result showed that 4.16 was more than 4.00 for the usability of the evaluation item and that the usability of LSV was high from this result. The result also showed knowledge of evaluation item recorded 4.32, which is more than 4.00 and from this result showed that students' knowledge was high. In addition, the overall mean for this student motivation evaluation item was 4.20 , which is more than 4.00 and the result showed that the student motivation was also high. Table 4 presents the results of the usability evaluation of LSV, Table 5 presents the results of the knowledge evaluation of students while Table 6 presents the results of the motivation evaluation of students. 
INTERNATIONAL JOURNAL OF ACADEMIC RESEARCH IN PROGRESSIVE EDUCATION AND DEVELOPMENT

Vol. 10, No. 1, 2021, E-ISSN: 2226-6348 @ 2021 HRMARS

\section{Table 4}

The results of the usability evaluation of LSV

\begin{tabular}{|c|c|}
\hline Items & Mean \\
\hline 1. Video has accurate information. & 4.27 \\
\hline 2. Video has reliability. & 4.19 \\
\hline 3. The visual quality is clear. & 4.27 \\
\hline 4. The audio quality is clear. & 4.04 \\
\hline 5. Images, audio and video contribute to understanding. & 4.19 \\
\hline 6. The information in the video is easy to follow. & 4.25 \\
\hline 7. The video looks smooth and in no hurry. & 4.12 \\
\hline 8. Video has a high value of teaching. & 4.23 \\
\hline 9. The title and description of the video are clear $\&$ appropriate. & 4.19 \\
\hline 10. Appropriate video duration. & 4.08 \\
\hline 11. The graphics or images used are interesting \& appropriate. & 4.12 \\
\hline 12. The colors used are attractive \& appropriate. & 4.09 \\
\hline 13. Attractive and appropriate animated movement. & 4.08 \\
\hline 14. Characteristic vectors (individual graphic) are interesting \& appropriate. & 4.12 \\
\hline Overall Mean & 4.16 \\
\hline
\end{tabular}

\section{Table 5}

The results of the knowledge evaluation of students

\begin{tabular}{|c|c|}
\hline Items & Mean \\
\hline 1. This module provides knowledge on visualization. & 4.27 \\
\hline 2. This module provides knowledge about goal. & 4.34 \\
\hline 3. This module provides knowledge about attitudes. & 4.27 \\
\hline 4. This module provides knowledge on emotional intelligence. & 4.33 \\
\hline 5. This module provides information on information technology. & 4.30 \\
\hline 6. This module provides knowledge on time management. & 4.37 \\
\hline 7. This module provides knowledge on learning practices. & 4.34 \\
\hline 8. This module provides knowledge on note. & 4.31 \\
\hline 9. This module provides knowledge on memorizing. & 4.25 \\
\hline 10. This module provides knowledge about examination. & 4.31 \\
\hline 11. This module provides knowledge on excellent student learning strategies. & 4.37 \\
\hline Overall Mean & 4.32 \\
\hline
\end{tabular}


Vol. 10, No. 1, 2021, E-ISSN: 2226-6348 @ 2021 HRMARS

\section{Table 6}

The results of the motivation evaluation of students

Items Mean

1. In following a module like this, I prefer challenging module content so that I 4.09 can learn new things.

2. If I focus on learning and following this module in the right way, then I will 4.31 be able to master the learning strategies in this module

3. I am not afraid to face exams because I know how to face them. 4.11

4. I think I will be able to apply what I learned in this module in my studies. 4.23

5 . I believe I will get an excellent grade 4.12

6. I am sure I can understand this module despite the difficulties. 4.13

7. Getting a good grade is the most satisfying thing for me right now. 4.43

8. When facing an exam, I will use strategies to face it. 4.31

9. This is my own fault, if I do not learn after following this module. 4.19

$\begin{array}{ll}\text { 10. It is important for me to study this module. } & 4.19\end{array}$

11. After following this module, the most important thing for me now is to 4.34 improve my achievement grade.

12. I am confident I can learn the concepts taught in this module. $\quad 4.20$

13. If possible, I would like to get a better grade than most other students. $\quad 4.43$

$\begin{array}{ll}14 . \text { When taking exams, I think of success in exams. } & 4.30\end{array}$

15. I can understand the content presented in this module. 4.11

16. I prefer the content of the module which arouses my curiosity, though it is 4.06 difficult to learn.

$\begin{array}{ll}\text { 17. I am very interested in the content of this module. } & 4.23\end{array}$

18. If I try hard, I will understand the content of this module. 4.25

19. After following this module, I no longer feel restless and upset when I want 4.18 to take the exam.

20. I am confident that I can study and get good exam marks after following $\quad 4.13$ this module.

21. I am confident I will be able to do my best in class later. 4.15

22. The happiest thing for me in following this module is that I try to 4.16 understand it to the best of my ability.

23. I think the content of this module is useful for me to learn. 4.23

24. When I have the opportunity to follow this module, I choose to study this 4.12 module even though it does not guarantee.

25. If I do not understand the content of this module, it is because I do not 4.18 work hard to try to understand it.

26. I like this module. $\quad 4.13$

27. Understanding the content of the module on this learning strategy is very 4.15 important to me.

28. My motivation for success increased after following this module. 
Vol. 10, No. 1, 2021, E-ISSN: $2226-6348$ @ 2021 HRMARS

\begin{tabular}{lc}
\hline $\begin{array}{l}\text { 29. I am confident I can master the learning strategy skills taught in this } \\
\text { module. }\end{array}$ & 4.13 \\
\hline $\begin{array}{l}\text { 30. After following this module, I want to do my best because I want to show } \\
\text { my abilities to family, friends and others. }\end{array}$ & 4.23 \\
\hline $\begin{array}{l}\text { 31. Given my seriousness in following this module, I think I will succeed after } \\
\text { this. }\end{array}$ & 4.16 \\
\hline & Overall Mean \\
\hline
\end{tabular}

\section{Discussion and Conclusion}

The usability level of the LSV to be implemented is at a high level above the 4.0 value, which reaches a mean value of 4.16. Therefore, the LSV can be used for the teaching to students for enhance high achieving student learning strategies. Usability is the extent to which a product can be used by the targeted consumer to achieve a set goal with effectiveness, efficiency and satisfaction in a particular use of context (Geisen \& Bergstrom, 2017). This student's knowledge evaluation contains a total of 11 items and recorded a mean value of 4.37 . All these items get more than 4.0 which is not a single item whose value is below 4.0. This indicates that every student has understood and at a high level of knowledge of high achieving student learning strategies after using the LSV which uses digital storytelling. According to Yang and Wu (2012), students can further enhance their understanding by learning through a digital storytelling approach. This student's motivation evaluation contained a total of 31 items and recorded a mean value of 4.20. All these items get more than 4.0 which is not a single item whose value is below 4.0. This shows that all students are at a high level of motivation to study and ready to get a good grade at university. The findings of Girmen, Özkanal, and Dayan (2019) study show where by using digital storytelling in learning, students' attitudes and motivation will also increase. The use of digital storytelling in learning is also supported by Chiew et al. (2019) where digital storytelling has been able to increase motivation and knowledge to students. According to Rashid and Akram (2019), motivation is an important element to facilitate students to initiate actions to use different learning strategies based on the level of student motivation. If students are highly motivated, the tendency for students to use high achieving student learning strategies is also high.

The implications of this research are for student learning practices and lifelong learning. Students can use these learning strategies as a student learning practice to achieve good academic achievement. In the meantime, students can also use these learning strategies to boost work efficiency and quality of life in the future. The main contribution to this research is that students can learn high achieving student learning strategies where they can emulate it and subsequently practice in their learning. Students can apply this effective learning strategy to achieve excellent academic results where they have previously learned according to their learning strategy. Digital storytelling approach can help students in understanding high achieving student learning strategies and in turn can visualize these strategies in the minds of students. Further research should be done to explore a different approach to methodology and online learning. For a methodological approach, researchers can use agile practices for software development that contribute to values and improve the agility of software professionals. The online learning could be the massive open online course or a $\mathrm{MOOC}$ based on the learning theory 
INTERNATIONAL JOURNAL OF ACADEMIC RESEARCH IN PROGRESSIVE EDUCATION AND

DEVELOPMENT

Vol. 10, No. 1, 2021, E-ISSN: 2226-6348 @ 2021 HRMARS

of connectivism. Subsequent research on different topics should also be considered using a digital storytelling approach that can be taught to students in a more engaging environment.

\section{References}

Bradford, L. E. A., \& Bharadwaj, L. A. (2015). Whiteboard animation for knowledge mobilization: A test case from the slave river and delta, canada. International Journal of Circumpolar Health, 74, 1-9.

Branch, R. M. (2009). Instructional Design : The ADDIE Approach. Springer Science \& Business Media.

Chiew, A., Leong, H., Jafre, M., Abidin, Z., \& Saibon, J. (2019). Learners' Perceptions of the Impact of Using Digital Storytelling on Vocabulary Learning. Teaching English with Technology, 19(4), 3-26.

Chiriacescu, B., Chiriacescu, F., \& Miron, C. (2020). Whiteboard animation - A tool for teaching the special theory of relativity. AIP Conference Proceedings 2218, 060006(March).

Cohen, L., Manion, L., \& Morrison, K. (2018). Research Methods in Education. Routledge.

Geisen, E., \& Bergstrom, J. R. (2017). Usability Testing for Survey Research. Elsevier.

Girmen, P., Özkanal, Ü., \& Dayan, G. (2019). Digital storytelling in the language arts classroom. Universal Journal of Educational Research, 7(1), 55-65.

Gladstone, B. M., \& Stasiulis, E. (2019). Digital Storytelling Method. Handbook of Research Methods in Health Social Sciences.

Lambert, J. (2007). Digital storytelling cookbook. Digital Dinar Press.

Lambert, J. (2013). Digital storytelling: capturing lives, creating community. Routledge.

Ormrod, J. (2017). Educational psychology: Developing learners. In Educational psychology: Developing learners. Pearson Education.

Poletti, A. (2011). Coaxing an intimate public: Life narrative in digital storytelling. Continuum : Journal of Media \& Cultural Studies, 25(1), 73-83.

Rashid, S., \& Akram, R. (2019). Relationship between the levels of motivation and learning strategies of prospective teachers at Higher Education level. Bulletin of Education and Research, 41(1), 57-66.

Robin, B., \& McNeil, S. (2012). What educators should know about teaching digital storytelling. Digital Education Review, 22, 37-51.

Robin, B., \& McNeil, S. (2019). Digital Storytelling. The International Encyclopedia of Media Literacy.

Smeda, N., Dakich, E., \& Sharda, N. (2014). The effectiveness of digital storytelling in the classrooms: A comprehensive study. Smart Learning Environments, 1(1), 6.

Türkay, S. (2016). The effects of whiteboard animations on retention and subjective experiences when learning advanced physics topics. Computers and Education, 98, 102114.

Wong, L. (2009). Essential study skills. Houghton Mifflin Company.

Yang, Y.-T. C., \& Wu, W.-C. I. (2012). Digital storytelling for enhancing student academic achievement, critical thinking, and learning motivation: A year-long experimental study. Computers \& Education, 59(2), 339-352.

Yusoff, M. A., Karim, A. A., \& Norman, H. (2019). Neuro-linguistic Programming Modelling : 
INTERNATIONAL JOURNAL OF ACADEMIC RESEARCH IN PROGRESSIVE EDUCATION AND DEVELOPMENT

Vol. 10, No. 1, 2021, E-ISSN: 2226-6348 @ 2021 HRMARS

Learning Strategies Used by High Achieving Students in UKM. International Journal of Academic Research in Progressive Education and Development, 8(4), 429-435. 